\title{
Spirituality and Moral Values
}

\author{
Evgeniia Erenchinova, and Elena Proudchenko \\ Department of international communication, Tyumen Industrial University, Tyumen, Russia,
}

\begin{abstract}
Since ancient times philosophers have been concerned with the issues of spirituality. The characteristic of the personality from the spirituality viewpoint gives the chance to see in a person the already created moral values. These values are reflected in his/her education and reactions to the arising situations demanding instant actions. It is important to underline that the spiritual world of a man is formed both within the religious and the secular system. In this article, the authors tried to show the difference between spiritualty and morality and to present spirituality from the perspective of such moral values as "freedom" and "conscience". In this regard, a theoretical analysis was carried out and the definitions of "spirituality" given by philosophers of some epochs were proposed. Moreover, the authors find it necessary to present such concepts as "spirit", "morality" associated with the concept of "spirituality", as well as views of some ancient, Western and Russian philosophers. The article also describes spiritual values such as «morality», «freedom», and «conscience». The authors come to the conclusion that conscience is the highest measure of morality, which determines man's spiritual world and culture.
\end{abstract}

\begin{abstract}
"One must gain a state of spirituality, or infusion of the Being, where Being overshadows all else and not spend his time cultivating a moral virtue that has an underlying motive behind it, because in time of testing the morality stands to be lost." (Charlie Lutes)
\end{abstract}

Before we start a theoretical analysis, we find it extremely important to explain the difference between spirituality and morality. The spiritual life reveals the one essence in all, but reveals too its infinite diversity; it works for diversity in oneness and for perfection in that diversity. Morality lifts up one artificial standard contrary to the variety of life and the freedom of the spirit. Creating something mental, fixed and limited, it asks all to conform to it. All must labour to acquire the same qualities and the same ideal nature. Morality is not divine or of the Divine; it is of man and human. Morality takes for its basic element a fixed division into the good and the bad; but this is an arbitrary notion. It takes things that are relative and tries to impose them as absolutes; for this good and this bad differ in differing climates and times, epochs and countries. The moral notion goes so far as to say that there are good desires and bad desires and calls on you to accept the one and reject the other. But the spiritual life demands that you should reject desire altogether.

In this regard, it is necessary to mention that the problem of spirituality arises in the process of any society formation. The spiritual world of a man is formed within both the religious and the secular system, so the concept of "spirituality" is considered much wider. The principles of openness, honesty, freedom, equality allow to create an environment for the spirituality development and preservation. The synthesis of knowledge of these principles gives a three-dimensional picture of the world.

Studying spirituality as a set of regulatory and organizing prerequisites philosophy affects the processes of self-organization of the individual's cultural education and makes them purposive.

This seems particularly important in connection with the economic crisis, followed by a crisis of spirituality. The crisis of the life spiritual foundations appears in the "lost generation" problems, lack of social security, destruction of any society values system and the lack of moral guidelines and values of individual's behavior. In order to comprehend the concept of spirituality and its problems, it is necessary to philosophically determine what cultural values and norms, behavior patterns can be offered as human activity reference points.

Bertrand Russell, a well-known thinker (1872-1970) wrote, "philosophy is a reflection on subjects of which knowledge is not yet possible." He showed that "spirituality" phenomenon is still only the subject of philosophers' reflection. This phenomenon is studied by many authors, but the concept of "spirituality" has not been clearly defined and unambiguously interpreted. At all times philosophers from different countries analyzed phenomena that have become integral parts of the spiritual phenomenon. Descartes, for example, wrote about wisdom, Kant wrote about the supernatural inner effort, etc.

Since the mid-twentieth century, researchers have begun to identify and systematize possible phenomena of the spirituality phenomenon. Spirituality was considered

* Corresponding author: deutsche2011@ mail.ru 
by researchers as: the ability of man to create his own world; way of being human that sets values of his life, being the fundamental quality of a man (V. S. Barulin, D. I. Dubrovskiy, A. V. Ivanov, N. N. Moiseev, E. P. Nikitin, G. V. Platonov, I. V. Fotieva, V. N. Cherdakov, M. Y. Shishin, A. I. Yatsenko); sum of a man's positive qualities (V. P. Veliky, V. P. Kiselev, A. V. Pletnev); description of consciousness, reflecting the dominant type of values (L. p. bueva, V. G. Fedotova); integral quality of a man formed by his social and social needs (G. E. Burbulis, T. T. Vlasenko, Yu. P. Vyazemsky, M. S. Kagan, V. E. Kemerov, P. V. Simonov); the relationship of spirituality and culture; the equivalence of the physical, social and spiritual worlds; the human ability to self-express and self-educate (M. N. Zelenetskiy, E. V. Sokolov, S. S. Batenin, A. Bochkareva, G. Zinchenko, etc.).

B. N. Kocherga and E. G. Yakovlev identified the system-forming properties of individuality as properties of integrity and spiritual dominants of historical development and worldview systems. Because of the variety of definitions of spirituality existing today, there is a need to determine the subject field of the phenomenon, which will help to approach its holistic understanding of the concept of spirituality from the standpoint of the anthropological foundations of existence, to see and determine the relationship of the spirit, soul with moral values, such as freedom and conscience.

Spirituality appears in rational; therefore, it can be fully revealed only in the system. What is the measure to weigh the interests of different people? How to compare different values? They may be incomparable, but people should at least know about them when making decisions.

The understanding of spiritual intentions of humankind takes place within the framework of humanitarian disciplines, in which there is an increase in the ethical component. Ethics acquires the features of the philosophical science considering human responsibility to himself. The man's responsibility assumes a philosophical ethical review of his activities. An expert measure of human responsibility, for example, can be a means to achieve the goal he has chosen. In the area of Supreme expediency, the Jesuit principle of "the end justifies the means" is unacceptable. A worthy goal requires decent means. In the sphere of the spiritual, the goal chooses only worthy means.

The way out of the protracted crisis is through the appeal to the spiritual time-tested values. N.I. Shevchenko writes, "Spiritual values are the makers of the human being. They are creative and constructive mechanisms working to stabilize the society, to prevent its destruction, this is their regularity." [1].

Spirituality represents the basis of self-existence, that harmonic core of the external and internal state of the individual, which allows each act of life to be endowed with higher moral and aesthetic or religious values. Spirituality does not exist outside the value approach.

The concept of "spirituality" is derived from the "spirit". Since ancient times in the Russian language, this term refers to what is opposed to the "matter" which is the substantial basis of being.
In the "Explanatory dictionary of the living Great Russian language" V.I. Dal says that "spirituality is a spiritual state. Spiritual, ethereal, not corporeal, consisting of only spirit and soul ... all that belongs to the human soul, all his mental and moral powers, his mind and will "[2].

In his "Dictionary of the Russian Language" S.I. Ozhegov considers spirituality as "the property of the soul, consisting in the predominance of spiritual, moral and intellectual interests over material ones" [3].

V. Frankl in his work "Man in the search for meaning" wrote, "The spirit is where there are events, i.e. relationships between self-being and being." "Spirit is presence."

"The possibility of a spiritual being to co-exist with another being is the original ability of the spiritual existence, spiritual reality" [4], i.e. here Frankl V. speaks of spirituality as an aware being, which reveals, connects, unites and comprehends the existence of another being. The spirit reveals itself as a meaningful being, as a value in itself. Its significance is self-evident. Unlike the soul, the spirit was originally understood as the free creative principle of the cosmos and of any particular thing. Berdyayev N.A. wrote, "Spirit is freedom. The spirit does not know the externality, does not know the objective objects that compel it. In the spirit everything is determined from the inside, from the depth "[5]. To be in the spirit means to be inside yourself. The saying "you are not in the spirit today" means you have no freedom, the demon has settled in you, you do not control yourself and your actions, ie be in the spiritual means to be in harmony with your ideals and attitudes, to gain true freedom means to go into the spiritual world.

Spirituality is considered in terms of 1 . religious experience; 2 . moral values; 3 . aesthetic principle, i.e. it is based on the understanding of the human being as unity, morality and beauty. As far back in antiquity a person was named kalocagatia - the term by which Plato denoted the ideal of education for the Greeks, that is, a combination of nobility, wealth, physical and spiritual abilities. The Greek's kalokagathia was rather socioethical concept than ethical and aesthetic, as kalokerinos (man, raised in the spirit of kalokagathia) had to provide himself at the disposal of society, i.e. here the ideal of man was recognized as a unity, or truth, goodness and beauty. A handsome man was thought to be kind and kindness could not be ugly. The Greeks spirituality did not exist apart from the embodiment. Aristotle said, "the soul is the entelechy of the body." The simplest understanding in antiquity was as follows: a man was thought as the unity of his aesthetic and moral principles, the unity of macro and microcosm, i.e. a man was a reflection of the interconnectedness of cosmic forces, harmony and order. He obeys the precepts of both the divine principle and the moral consciousness in spirituality, for example, in antiquity, virtue was considered as an aspect peculiar to a man. So the virtue means that a man constantly communicates with the whole world, and it is perceived through the principles of justice, good, measurement and equality. For example, Pythagoras formula of justice says the number multiplied 
by itself is the law working in the universe, the law of spirituality, the principle: "as you sow you will mow."

The values prevailing in society are different in their subject matter. Thus, spirituality can be represented by such types:

- aestheticism (where beauty is the dominant value);

- theorism ( where the dominant value is the truth), which is divided into materialism and idealism;

- atism (the dominant value of which is good, the desire to appreciate life with the moral position), as well as individualism, collectivism, unity, community;

Spirituality in terms of different types of human activity was considered by such researchers as M. M. Bakhtin , R. L. Livshits, V. G. Fedotov. This typology can be further developed as:

- religiosity (the source of moral norms is thought to be the will of God);

- politicism (desire for power);

But the need to classify the spirituality on the grounds of religion and secularism is talked more often about.

All these types of spirituality are real life unilateralisms, generated by the division of labor and the absolutization of various aspects of spiritual activity.

Religious thinkers insist on the transcendent essence of spirituality, when a person feels the value of life through the ability of a person to go beyond his self, the ability of sensual and super-sensitive communion with nature, to society. So there appears not only an intellectual, but also a sensual communion to the highest values. Thus, spirituality is understood as an intersubjective property with positive value qualities.

In the religious Christian tradition, the spirit of God is the power that God spiritualizes, encourages, strengthens. The very concept of spirit is filled with personal content as it is supposed to be a personal absolute, the personal will of God. When understanding the philosophy of Christianity, the interpretation can be as follows: the spirit is the logo, the concept, the law, the original essence (substance), or an absolute I - identity. Spirituality is opposed to soulfulness-the totality of everything that does not go beyond psychological processes. In contrast to the "soulful" the "spiritual" is cleared of disguised impulses of self-will, selfishness, sensuality, and aggressiveness. Therefore, spirituality in Christian ethics is associated with inner purity and tranquility, with modesty and obedience.

Thus Russian philosophy has always been focused on logos, which implies spirituality of the world.

In the Eastern tradition (India), the spiritual beginning of the world is called Brahman. He creates the world with his exhale giving birth to things and incarnating in them, i.e. he is understood as the only subject in the world.

Any person associates the concept of "aesthetic" with the feeling of something beautiful, pleasant to the eye, hearing, associated with a sense of comfort of the soul and body. Such feelings are usually brought to a person by art. Painting, sculpture, music, literature, theater, architecture, etc. - all these are created by humankind and belong to art, which is a special aesthetic vision of reality, a means of its improvement.
Hegel G. V. F. in his "Aesthetics" says that art was the first teacher of humanity. But it not only conveyed and still conveys the knowledge and spiritual content of different epochs and peoples, but also brings up the culture of feelings and sensations in people such as aesthetics and spirituality.

German classical philosophy explained nature as the moment of the materialization of the absolute spirit. In his work" Philosophy of spirit "Hegel writes:" the Spirit is not something that is at rest, on the contrary, there is something absolutely restless which is pure activity, so the essence of the spirit is formally freedom, as the substance of the spirit is freedom. This allows him to reach the tops of the universe, to be perfect, boundless and infinite. This allows you to create any ultimate integrity, to bring complicity to each of your actions, the meaning of each on personal being "[6].

G. Hegel's work are addressed not to religious interpretation, they are talking about the essence of man himself for him, for him the formation of the spirit is the formation of the logos in the formation of mankind, because he speaks not about the abstract, but about what we can see in the history of mankind.

The development of the spirit by G. Hegel lies in the fact that it is 1) in the form of relations to itself (the subjective spirit); 2) in the form of reality as to be a product of the spirit (objective spirit); 3 ) as a self that exists, the eternally generating itself unity of the spirit objectivity and its ideality, i.e. the absolute spirit.

Spirituality of life can be perceived through ideals, values, preferences and through the model of human activity.

Spirituality of a contemporary man involves a harmonious union of the above types.

Complex spirituality is the unity of truth, goodness and beauty. The main criteria of such spirituality can be:

- intentionality - i.e., the direction "out" on something or someone.

We are talking about setting ideal goals, which is already an indicator of a spiritually developed person;

- reflection on the basic life values that make up the meaning of a man's being and acting as a guide in life choices;

- freedom, understood as self-determination, i.e. the ability to act in accordance with one's goals and values, and not under the pressure of external circumstances;

- creativity - understood as creation of oneself, aimed at the realization of one's life purpose;

- developed conscience - is something which a person is responsible to for the implementation of his life purpose, as well as for everything that happens in the world.

The criteria of spirituality is considered and described by such researchers as N.A.Berdyaev, V. Frankl, E. Fromm, T. de Chardin, M. Scheler, etc.

The concept of human spirituality is a system of values of the individual, his ideas about himself, through the behavior determining will. It is a hierarchy of values, where the "highest values" of the spirit, subordinating the values of the flesh, are the main ones. Considering the concept of spirituality N.K.Borodina believes that: "spirituality is the inner sphere of a man's personal 
identity, his a priori ability to build his own world of claims and assessments, and to reflect reality through his intellectual and moral-psychological potential (the world of things and the human world) according to his ideal of life and human dignity" [7]. She supposes this understanding of spirituality to be comparable to the concept of intelligence, which is tightly closed within the individual.

The moral component of spirituality is based on the concept of freedom of will outside the legal concept, and free acceptance, free, conscious, choice of the man and the ability to bear responsibility for it. Morality is socially-oriented. Is it possible to be moral with yourself? For example, a moral person in a desert where there is no one is responsible to himself and has a choice in his actions to himself, either to lie down and die without making any effort to fight for life, or to go forward and fight for his life - that is said to be the absolute inner sense of freedom. As the dominant beginning, one can call moral consciousness, the moral ideal. What human action can be called completely moral? The one which is deprived of personal selfish interest, free and selfless.

Marx and Engels wrote, "Man is responsible for his actions only if he has committed them with complete freedom of will, it is the moral duty to resist every immoral act" [8]. Spirituality is freedom, morality, defines our social character of freedom; i.e. freedom as the basis of moral consciousness in society is defined in 3 aspects: 1) as a measure of real freedom, depending on the nature of social relations; 2) as a dependence of personal freedom on the measure of civic maturity and value orientation; 3) as an opportunity for free choice of behavior. The ideal categories of the moral consciousness are the duty, humanity, goodness, justice, courtesy, honesty. A man without the moral inner core rushes through life like the "fragile boat" in a stormy sea. The central category of moral consciousness is conscience.

Watchman Nee writes, "the presence of the soul in the spirit, its openness to unlimited possibilities of the spirit in creativity, the constant thirst of the soul for perfection, freedom, integrity is nothing more than spirituality. To be born spiritually means to have conscience" [9]. Etymologically, conscience is the message. What is conscience? It is a connection to a thing, a connection to the highest, to humanity; we are connected with some news. The good news means that we are endowed with the news. Conscience is going beyond the soul; conscience is the voice of God in us. Or that internal discretion that speaks with actions.

Many moralists have determined the conscience as a higher capacity of understanding moral truth. Conscience is not normative, it cannot be taught, it cannot be said that it has awakened. It is a great gift like genius. Conscience is a doctor of the soul, healing it from sinfulness and suffering and bringing it to a new level of existence.

To sum up, it is necessary to consider that when developing and promoting moral values of the modern personality, he is influenced by society itself. Under the influence of the society, the prospects of the transformation of a man's social nature are revealed. There appears a difference between a "spiritual" person (" a cultured person") and a person of an intellectual "intelligent thinker" through an ethically oriented worldview. Today, people live in a communication space featured by the absence of time boundaries, the absence of economic restrictions. This allows to quickly find the needed information and communicate with people without vested interests. The contemporary "spiritual" man is actively involved in the society reconstruction, which was due to the information and communication development. Also, a "spiritual" man acquires a unique identity and self-sufficiency, self-worth.

Thus, spirituality involves the freedom of the individual. Forming his spirituality, a man ascends, rises to these ideals and realizes them in his life path. A man acquires conscience, i.e. the highest measure of morality, which determines his spiritual world, spiritual culture.

\section{References}

1. N. I. Shevchenko, Revival of spirituality: monograph (Belgorod: Izd-vo BGTU im. V.G.Shuhova, 2004)

2. V. I. Dal', Explanatory dictionary of the living Great Russian language (Moskva: Izdanie knigoprodavca tipografa M.O.Vol'fa 1, 1880)

3. S. I. Ozhegov, Explanatory dictionary of the Russian language (Moskva : Azbukovnik, 2000)

4. V. Frankl Man in search of meaning (Moskva. "Progress", 1990).

5. N. A. Berdjaev Philosophy of the Free Spirit (Moskva: Respublika, 1994).

6. G. Gegel' Lectures on the philosophy of the spirit (Moskva: Izdatel'skij dom «Delo» RANHiGS, 2014).

7. N. K. Borodina Spirituality: Phenomenon and Understanding (Volgograd: Volg. GASA, 1999).

8. K. Marks Works in 50 volumes (Moskva 21, 1961)

9. Ni. Vochman, Spiritual man http://ministrybooks.ru/?mb=518 (data of access: 15.04.2018).

10. S. Cotton, K Zebracki, S. L Rosenthal, J. Tsevat, and D. Drotar, Journal of Adolescent Health 38(4), 472-480 (2006).

11. T. R. McCormick, F. Hopp, H. Nelson-Becker, A. L Ai, J. O. Schlueter, J. K. Camp, Journal of Religion, Spirituality and Aging 24(4), 301-313 (2012)

12. R. N. Nigmatulin Philosophical Analysis of the Ontological Aspects of Fate and Freedom of Will: Avtoref. dis. na soisk uchen. step. kandidata filos. Nauk (Magnitogorsk, 2000 ) 